\title{
Bridging the gap between culture, identity and image: A structurationist conceptualization of place brands and place branding
}

\begin{abstract}
Purpose: Although place branding is increasingly popular in research as well as in local, regional and national political agendas, the theoretical foundations of the place branding discipline are still underdeveloped. By embracing the stream of identity-based studies, the paper attempts to demonstrate that place brands can be usefully approached through an emphasis of their cultural traits and the practical connection between culture, identity and image.

Design/methodology/approach: In constructing its theoretical arguments, the paper challenges the place branding model propounded by Kavaratzis and Hatch (2013), and uses practices as units of analysis. The paper conducts a brief review of the principal tenets of practice theory(ies) and uses structuration theory as a theoretical device to demonstrate how this theory can provide a (still lacking) theoretical anchorage for the place branding process.

Findings: The usefulness of structuration theory for understanding the place branding process is analysed at both the strategic and tactical levels by means of two illustrative examples. Structuration theory proves to be a solid theory which links the constitutive elements of the place branding process, i.e. culture, identity and image, and to inspire further theoretical elaborations and empirical efforts grounded on this theory.

Originality/value: This is the first article which employs practice theory(ies) in general and structuration theory in particular to explain the place branding process. The theoretical arguments advanced provide valuable guidance for further theoretical elaborations and empirical applications.

Article type: Conceptual paper
\end{abstract}

Keywords: Place branding, practice theory, structuration, culture, identity, image. 


\section{Introduction}

In this article, we examine the formation and operation of place brands under the theoretical light of practice theory and, specifically, of Giddens' (1984) structuration theory. In doing so, we aim at advancing the theoretical understanding and grounding of place branding by emphasizing the central importance of what we see as the main constituent of place brands and of the main element that may form the basis of the place branding process: practices. The use of structuration theory allows us to explore in depth the dynamics of place brands at several levels: first, at the strategic level where the place brand is treated as the strategic vision for the development of the place; then, at a tactical level of specific place branding initiatives and actions aimed at communicating the place brand; finally, and perhaps more importantly, at the level of individuals and their mutual influence on the place brand, its formation and communication. Using structuration, we are able to provide a strong anchorage for practice theory and understand how people's practices ultimately shape what is to become the place brand.

The need for an elaborate discussion of theories relevant to place branding stems from our agreement with the criticism raised by scholars (see amongst others Ashworth et al., 2015 and Lucarelli, 2018) that little theoretical refinement seems to have occurred in the last twenty years, despite the proliferation of studies in the field. Place branding is thought to support place development through the establishment and maintenance of a favourable and consistent image and reputation of the place (Papadopoulos, 2004; Gupta et al., 2018). This has led some to attempt to formulate managerial processes to exploit it and increase the competitiveness of the place (Van Ham, 2008; Moilanen and Rainisto, 2009; Rojas-Méndez et al., 2015), while others have treated it as part of an implicit political agenda that exacerbates social problems (Colomb, 2012; Greenberg, 2008). A large part of the literature has focused on attempts to define place branding and its potential (Govers and Go, 2009; Anholt, 2010) and discussions of how this might be put into practice (Braun, 2012; Eshuis et al, 2013). This article attempts to position itself amongst another series of publications characterized by a cultural approach to place branding aimed at establishing 
cultural explanations of the process through which place brands are created (Askegaard and Kjeldgaard, 2007; Kalandides, 2011; Mayes, 2008).

In particular, we draw on the 'identity-based place branding' model suggested by Kavaratzis and Hatch (2013) to simultaneously challenge it and complement it. Using structuration theory as our theoretical device and practices as our units of analysis enables us to bring an additional focus and nuance to their description of the dynamics of place brands.

Despite its theoretical nature, and although this article has as its primary objective that of reinvigorating the theoretical debate in the stream of place branding research, it also offers a new light under which the practice of place branding can or should be seen. Emphasizing the need for place branders to focus more on practices in the development of their branding strategies and in the deployment of place branding tactics can allow place branders to address their branding efforts better, to prevent brand failures, and to develop brands that are more solidly linked to what the place actually is and how external audiences should see it.

The article starts with our perspective on the place branding process that highlights the actions and practices that constitute the place brand. We then explain how practice theory in general and structuration theory in particular informs our understanding of places. Thereafter, we demonstrate how structuration theory can help to achieve a better theoretical understanding of place culture, identity and image, indicating that the interplay between the three occurs through peoples' practices. Two illustrative examples of different levels of place branding activities (strategic and tactical) are then presented to explain the theory in practice. Cases are used as practical illustrations to support the theoretical and empirical relevance and plausibility of arguments proposed and to illustrate the operation of the underlying mechanisms (Siggelkow, 2007). Finally, we outline the main implications of our theoretical proposition with particular regard to the contested nature of identity claims and taglines and the fallacy of the persisting division between internal and external audiences for place branding activities. 


\section{Understanding the place brand: From logos to culture}

Although scholars have not (yet) reached agreement on the meaning of place brands or the process of place branding (Gertner, 2011; Kavaratzis, 2017), the literature of the last two decades reveals progress in defining place brands and a gradual shift by scholars from a normative inspired definition to a cultural rooted one. The first definition of place brands adopted was that provided by the American Marketing Association (AMA) for the brand in general by simply substituting the terms 'goods' and 'services' with that of place. Accordingly, a place brand has been defined as 'a name, symbol, logo, word mark or other graphic that both identifies and differentiates the destination [that] conveys the promise of a memorable travel experience that is uniquely associated with the destination [and that] serves to consolidate and reinforce the recollection of pleasurable memories of the destination experience' (Ritchie and Ritchie, 1998:103). This definition highlights the brand's functions of identification/differentiation, and adds some elements related to the experiential value of the place for brand recipients.

More recently, place branding has been more compellingly defined as the process of building the brand of a given place by drawing on its identity and by promoting the formation of a positive place image (Anholt, 2010). By acknowledging the limits of the 'AMA inspired' definition, scholars have gradually moved toward a focus on the cultural foundations of the place brand, and criticised normative approaches to place branding (Ashworth and Kavaratzis, 2009).

Place brands are now increasingly analysed in terms of the cultural values they carry, and the place branding process is regarded as a production of cultural meanings (Campelo et al., 2013; Kavaratzis and Kalandides, 2015). Parkerson (2007:263) clearly stated, '[...] place brands are inherently different from products and product brands and conventional branding models and approaches are insufficient. Viewed through the lens of culture, in its many meanings and manifestations, place branding takes on a new complexity'.

The growing acknowledgment that brands are cultural artefacts (Cayla and Arnould, 2008; Schroeder, 2009) created through a negotiation of meanings among individuals (Lury, 2004; Merz 
et al., 2009; Ind and Coates, 2013) has also been transferred to the place branding field (Warnaby, 2009; Kavaratzis and Hatch, 2013). Scholars have stressed the need to connect place branding activities with the local culture (Morgan et al., 2003; Hankinson, 2005; Kavaratzis and Ashworth, 2015), and emphasized the connection with the place identity (Houghton and Stevens, 2010; Therkelsen et al., 2010). If the brand of a place is not anchored to its identity, the process of place branding will lead to an empty brand meaningless especially to its internal audience (Pasquinelli and Teräs, 2013). In other words, the starting point for developing the place brand is the place's identity (Kavaratzis, 2004; Zimmerbauer 2011, 2016). The adoption of this perspective also requires framing the notion of place in a different way. Places cannot be simplistically identified with geographical and/or political borders (Harrison and Dourish, 1996); rather, they should be regarded as imaginary representations of social relations constituted by sedimented social structures and cultural practices (Escobar, 2001).

Drawing on this ontological perspective of places, Kavaratzis and Hatch (2013) have theoretically outlined the identity-based process of place brand creation. The brand of a place, they argue, emerges as an outcome of the process of dialogue between stakeholders which is at the core of the development of the place identity. In this sense, the brand cannot be considered a managerial variable that place branders can fully control (Gardner and Levy, 1955), but instead as an entity created through the syncretic meeting of stakeholders (Askegaard, 2006; Hatch and Schultz, 2010). A better understanding of identity is of paramount importance also at a practical level, i.e. to 'execute' the place branding process and to compose a specific and appealing market proposition (Medway and Warnaby, 2014). A better understanding of the place identity can prevent place branders from incurring brand failures in their attempt to give a place a unique (but detached from its identity) brand image. For example, Vanolo (2008) has shown that the main reason why the process of rebranding an industrial city like Turin from its former image as the 'automotive capital of Italy' to the 'city of creativity', was the lack of a clear connection between the new positioning and the place's sedimented identity. Early in 2009 the city of Hamburg faced great resistance, and 
even the birth of an antagonistic movement (i.e. Not in our Name, Brand Hamburg), against the branding strategy pursued by the municipality, which was trying to rebrand the city's image emphasizing creativity to appeal the creative classes. The main argument behind the protest against the municipality's strategy to market Hamburg as the city of creativity was the inconsistency perceived by residents between the projected but not actually existent image and the actual identity of the place (see NION, Brand Hamburg, 2010; Zenker and Beckmann, 2013).

However, the fact that the image of a place should be aligned to its identity as much as possible should not lead to the conception of place identity as a fixed entity (Kavaratzis and Hatch, 2013). Rather, a place's identity is a dynamic 'object' that changes with the passage of time, and through a continuous 'dialogue' between internal and external stakeholders, as outlined in the next section.

\section{Place branding and place identity: the missing link}

Kavaratzis and Hatch (2013) outline the dynamics of place identity and place brands by drawing on the framework of identity formation developed by Hatch and Schultz (2002). This process is composed of four sub-processes that occur simultaneously and involve both internal and external stakeholders: 'expressing', which encompasses the process by which culture makes itself known through identification; 'impressing', which refers to the impression that identity leaves on others; 'mirroring', which refers to the process by which the image of others is reflected on identity; 'reflecting', which signifies the process by which identity is embedded in cultural understanding (Figure 1).

\section{- Figure 1 around here -}

As Kavaratzis and Hatch (2013) claim, effective place branding should allow or encourage locals to express cultural features that already form part of the place identity (expressing), tap the images of others by mirroring their impressions and expectations (mirroring), leave positive impressions on 
others (impressing) and, finally, instil new meanings and symbols into culture (reflecting). According to this reasoning, the most important element of place branding is neither the brand, nor the identity; rather it is the place brand construction process undertaken by stakeholders (both internal and external) through the interplay between culture, identity, and image (Kavaratzis and Hatch, 2013).

In this article, we attempt to build on this model and remedy what we see as its drawback, i.e. its inability to explain how each of the four sub-processes and the interplay among them is materially enacted leaving several questions unanswered: How does identity express cultural understandings? How does identity mirror the images of others? How does identity leave impression on others? How is identity embedded in culture?

Starting from these questions, we claim that the place branding process suggested by Kavaratzis and Hatch (2013) will benefit from a better understanding of practices that are enacted within a given place. We thus embrace a theoretical stance similar to that of others (see e.g. Warde, 2005; Kornberger, 2010; Vargo and Lush, 2015), according to whom a brand is far more than an object; rather, it is the result of a set of practices. We suggest that Kavaratzis and Hatch (2013) fail to describe how the four sub-processes occur through practices which are central to the development of the place identity (expressing), to the reflection of such identity in cultural change (reflecting), to the development of a positive image (impressing) and to the process of adaptation of the identity to the image it renders to audiences (mirroring). And, we argue, it is by examination of these practices that we can give theoretical and empirical answers to the questions mentioned above, i.e. How does identity express cultural understandings? How does identity mirror the images of others? How does identity leave impression on others? How is identity embedded in culture? These practices are the means by which individuals create the place across time and space (Gupta and Ferguson, 1992) and make its brand meaningful to both internal and external stakeholders. For example, the aforementioned case of rebranding Hamburg as the 'city of creativity' failed because the branding strategy was designed to emphasize some local practices to impress visitors, while neither taking 
into serious account the very basic cultural principles on which Hamburg collective practices are built, nor offering a convincing and suitable opportunity for local citizens to adapt their practices to fit better with the desired image. Place culture in this sense becomes the enactment of these practices, serving both as a guide for and as an outcome of social conduct. Place identity, similarly, is understood as the medium and outcome of a process of negotiation between self and social identity and between individual biographies and dominant social projects (Pred, 1984). Finally, place image can be considered as the result of reflexive understanding of routinized practices enacted in a given place, typical of that place, carried by knowledgeable actors either belonging or not belonging to that place. Thus, being a place of creativity means that the culture of that place has a clear orientation to creative practices, e.g. a number of 'creative-class people' higher than in other places; people living in that place see themselves as more creative than others due to the creative practices enacted therein individually and collectively; and because non-locals are able to differentiate the place from others (even equally creative ones) because of the distinctive placespecific creative practices enacted there.

Place culture, identity, and image are accordingly linked one to the other by practices. Because these practices are prevailingly routinized, they give shape to the culture of a place which results from the unique combination of (past) historical patterns that shapes present and future actions and interactions within it (Karababa and Ger, 2011; Kravets, 2012; Rojas-Méndez, 2013). Put in this way, the concept of culture becomes instable because it encompasses a ceaseless dynamic of change instantiated through human actions and interactions (Bourdieu, 1977).

If the connections between culture, identity, and image are untangled in this perspective, practice theory(ies) emerge as useful theoretical devices because they emphasize the influence that culture exerts in determining both social action/interaction and the wide range of micro and macro social processes (Reckwitz, 2002). Moreover, since practice theories are characterized by a common effort to provide a solution to the centuries-old dispute on the primacy of action over structure and vice versa (Schatzki, 1996), they are well suited to making theoretical and empirical sense of how the 
existence of a place brand is able to affect people's behaviour and, conversely, of how peoples' behaviour is able to change the very existence of the place brand. Differently stated, practice theories offer a solid theoretical argument and respective empirical agenda to regard (place) brands as socially constructed entities.

Furthermore, since practice theories have a common tendency to shift the focus from the outcome, i.e. the brand, to the process and to the activities whereby that outcome is produced (see Vargo and Lush, 2016 for a similar argument), the use of practice theory to theorize about place branding is also suitable for strengthening the link between place branding research and place branding practice.

Several sociologists and philosophers can be grouped under the heading of 'practice theorists'. The most eminent of them include Giddens, Bourdieu, Lyotard, Foucault, Taylor, and Schatzki. Although a detailed description of practice theory falls outside the scope of this paper (see Reckwitz, 2002 for a review), these authors share several features. They all situate practices as the means by which social life in chronically produced and reproduced. They all reject the dualisms between agency and structure. They all consider (social) relations to be mutually constitutive, i.e. they always exist in relation with each other (Feldman and Orlikowski, 2011).

Although practices are primary units of analysis in branding research (Cayla and Eckhardt, 2008; Thompson and Arsel, 2004), applications of the theory of practice to the study of branding are still scant (Warde, 2005) and non-existent in place branding research. In fact, research has largely approached these practices from a subjectivist perspective, paying limited attention to the links among individuals' experiences of brands, and the context(s) in which these brands are experienced (Askegaard and Linnet, 2011). However, although the existing theories of practice have similar theoretical roots, the "Structuration Theory" proposed by Anthony Giddens and the "Theory of Practice" outlined by Pierre Bourdieu (1977) are undoubtedly those most widely used in social research (Everts et al., 2011). In this article, we deliberately draw on Giddens' (1984) social theory and prefer this theory to Bourdieu's theory of practice due to our epistemological support for those 
critics that have revealed an objectivist bias in Bourdieu's theory (Schatzki, 1987, 1997; Jenkins, 1982; Mouzelis, 1995; King, 2000; Lizardo, 2010). These drawbacks impose serious constraints on our effort to propose a convincing theoretical conceptualization of place brands as social processes constructed through a dialectic interplay among stakeholders. In regard to Bourdieu's objectivistic tendency, to be accused especially is his problematic theorization of power that emphasizes agents' struggle to achieve domination over others. Power in Bourdieu's mind-set is used to explain persistent and hard-to-change social differences and unequal social structure (Bourdieu, 1994), rather than to make sense of individuals' willpower (Navarro, 2006) including their ability to change the social structure in which they act (Calhoun et al., 1993). As we seek to show as this article proceeds, Giddens grants agency a greater capacity to change social structures, and assumes a more 'neutral' understanding of power according to which even social stability is a form of social change.

Having a more balanced theoretical understanding of the relationship between agency and structure and of how power is involved in this relationship is of great importance in the context of branding since, as the literature reveals, the relationship between individual actors and brands is not necessarily permeated by power dominance or social struggles. Rather, this relationship can be shaped under the forces of a process involving the brand, the consumers, and other stakeholders (Merz et al., 2009), where none of these parties seeks to achieve dominance over the others.

Moreover, what makes structuration theory particularly suitable for the study of brands (regardless of whether they refer to a place, a corporation or a product) and of how brands shape and are shaped by human action, is the way in which the theory frames agency, i.e. as the capacity to do otherwise. In the consumption realm, consumers' agency is the capacity to freely, voluntarily and deliberately decide to erect a brand as an identity-signifier (Kuenzel and Vaux Halliday, 2008), to allow the brand to influence their way of thinking (Schroeder, 2009), or to attach to the brand meanings and values that are more traditionally associated with human beings (Fournier, 1998). Thus, choosing to enact some practices that are purposefully intended to benefit the brand (e.g. engaging in positive 
word-of-mouth or regularly taking part in brand fests or other brand initiatives) not only reinforces the role that the brand plays in one's life, but it also contributes to reinforcing the brand's role as a potent influencer or shaper of individuals' lives.

If this way of framing individual agency is important for disentangling how consumers relate to brands and vice versa in general, it is particularly useful when place brands are under scrutiny because their primary recipients, i.e. local citizens, are implicitly involved in the process of coauthoring the brand's meanings.

There are at least three important reasons why structuration theory is appropriate to advance current understanding of the place branding process. First, structuration theory directs attention to those local practices that may constitute the very essence of the place brand. Second, it makes it possible to evaluate how these local practices are synthesized into intangible brand meanings to become the structural constituents of the place brand. Third, it offers a solid theoretical lens through which to determine whether and how human agency is somehow influenced by the very existence of the place brand.

In line with structuration theory, we contend that a place brand cannot be taken for granted or assumed to exist because the brand is reified or advertised until the place is transformed into a structure, i.e. when the presence of the place brand is taken into account (more or less intentionally) as a guide for action.

Hence, while recognizing that Giddens' structuration theory is not free from drawbacks (see Archer, 1982, Stinchcombe, 1986 and Clegg, 1989 for fierce criticisms of the theory), we believe that this theory is well suited to making sense of the place branding process and - particularly - to bringing together place culture, place identity and place image. The principal tenets of structuration theory are concisely reviewed in the next section.

\section{Structuration theory}


The theory of structuration attempts to describe the relations between the overarching structures that influence our lives and our ability to exercise agency (Cresswell, 2004). Structures for Giddens depend on our actions to exist, and our actions are given meaning by the structures that lie beyond them (Cresswell, 2004). Individuals are engaged in structures that they transform in the action process (Sewell, 1992). Structures exist only as memory traces, are instantiated in action, and exist insofar as practices are conducted (Giddens, 1984, 1986). Structures characterize social systems because they form the rules of actions that individuals follow in a specific place, so that some practices can become institutionalized and assume a taken-for-granted nature, while others are not carried out because they are deemed inappropriate or illegitimate.

According to structuration theory, structures assume three different forms: signification, legitimation, and domination (see Figure 2).

- Figure 2 around here -

Structures of signification enable and constrain agents to make sense of the context in which they act and to communicate these meanings and their views of ongoing practices to others by drawing upon interpretive schemes. Thus, signification refers to discursive and symbolic rules that govern the way in which people talk and use interpersonal communication. Agents also refer to structures of legitimation via norms that imply sanctions of some form incurred when they are not respected. For Giddens, signification and legitimation are procedures of actions; therefore, they are aspects of praxis. Awareness of these structures is the core of the knowledgeability of human agents. To say that individuals are knowledgeable means that they know how to act in certain situations and adjust their actions accordingly. They are able to monitor their actions continuously and expect others to do the same (reflexive monitoring). They are able to maintain a continuous theoretical understanding of their actions (rationalization of action) and to act purposefully (motivation of action). Agents' knowledgeability is thus an important aspect of practice routinization since actors have a natural tendency to reproduce the social order that gave them the capacity to act. Yet, 
although motivation, knowledge and reflexivity are considered central principles of human agency, they should not lead one to think that every human action is thoughtfully undertaken and that Giddens has a subjectivist stance of human action. In fact, many of the social interactions and social practices that we perform on a daily basis are enacted in force of what Giddens calls 'practical consciousness', i.e. the individuals' tacit knowledge of how to act in the context of social life that is not necessarily reflected in their discursive ability to explain why they act in a certain way. Consider, for example, how we use a structure of signification like language (see Haslett, 2012). When an individual utters a sentence, s/he draws upon various linguistic rules that are sedimented in her/his practical consciousness of language usage. These structural features of the language are the medium whereby individuals generate utterances. But in producing a syntactically correct utterance they simultaneously (although largely unconsciously) contribute to the reproduction of the language as a whole. This is why Giddens claims that structures (such as language) and action (such as the act of speaking) have to be distinguished. Speech presupposes a subject, while language is somehow subject-less because it exists only in so far as it is known and reproduced by its speaker via its correct usage. The same applies to how individuals refer to structures of legitimation, e.g. legislative norms. A norm comes into actual existence only when it is transgressed (in the form of sanctions) and whenever people are discouraged from acting in a way that does not align with the norm, the effect is to reinforce the structure of legitimation to which the norm refers.

However, the fact that for Giddens agents have a general tendency to reproduce the structural conditions that allow them to act should not lead one to conclude that change is impossible in the structuration frame of reference. Change for Giddens is made possible through the enactment of power. For Giddens, action logically involves power because power is prior to subjectivity and is not a resource itself. Power is for Giddens related to structures of domination, i.e. 'the media whereby transformative capacity is employed in the routine course of social interaction' (Giddens, 1979:92). Therefore, if actors are powerful enough, their actions may have the consequence of transforming the structures that gave them the capacity to act, also limiting the power exercised by 
others. Accordingly, the enactment of power presumes the existence of relations of autonomy and dependence among individual and/or collective actors within the context in which social interaction occurs. This does not mean that when the actor cannot choose to act otherwise, power ceases to be salient (as in Bourdieu's theory). Power for Giddens is a transformative capacity also in the case in which it cannot be deployed. Thus, no change is always change because it consists in the practical re-production of the same structural dimensions that inhibited actors' willpower.

Time and space are of paramount importance in Giddens' theory because structuration occurs in spatially and historically contingent settings (Giddens, 1991; Pred, 1984). The passing of time is necessary for practices and interaction to become routinized and for structures to be institutionalized. Space is of equal importance because the process of structuration occurs in geographically bounded places (Giddens, 1979; 1984). However, as Giddens observes 'it is usually possible to designate locales in terms of their physical properties ... but it is an error to suppose that locales can be described in those terms alone' (Giddens, 1984). According to Pred (1983, 1984), in any given place there are certain institutional projects that are dominant (i.e. assume priority over others) due to the impact that they have on individuals' social conduct. The accomplishment of dominant institutional projects is intertwined with individual biographies that bring continuity to the structuration of social systems. Thus, dominant projects and individual biographies are both means and ends of one another. Structures of domination and the constituent interaction dimension of power relations among individuals, groups and institutions to a great extent determine the nature of projects that are possible or impossible to enact, the tension/resistances between individual biographies and institutional projects, and the quality and amount of resources that can be mobilized for the achievement of the objectives of such projects. Although power is prior to subjectivity, power is nonetheless also the capacity to force individuals to participate in particular projects, under specific distributions of power. On the one hand, institutional power has the ability to force individuals to behave in a certain way by producing or reshaping the structural conditions of microsettings of actions and interactions. On the other hand, actors can act individually or in social 


\section{Structuration theory and the interplay between culture, identity and image}

Giddens' social theory can advance our understanding of place branding. First, to focus on the recursive interplay between agency and structure, it makes it possible to avoid considering the brands of places as astray structures detached from the social reality that shapes them. Place brands - as structures - are first and foremost the loci of action. Thus, it can be argued that the meanings that a place brand possesses are neither settled nor independent from its recipients (including both internal and external stakeholders that contribute to the brand's creation, formation and maintenance). According to Giddens' theory, the brand and the meanings that it carries are continuously (re)negotiated and (re)shaped, making the place brand the result of both discursive and performative practices. 'Discursive' means here that the focus is on signs and language that coordinate action, while 'performative' means that the focus is more on material and bodily enactments.

Structuration theory also makes it possible to frame places at the crossroads between institutional projects and individual biographies. The place does not exist separately from the individual and collective practices that are enacted within it. Each place is characterized by a culture that exists only insofar as practices are conducted. When individuals act in a place, they refer - implicitly or explicitly - to the culture of that place, boosting the process of structuration of culture. The concept of culture thus assumes a meaning that goes beyond its role of shaping and providing meanings for the ways of doing things in a given society (Aitken and Campelo, 2011; Kavaratzis and Hatch, 
2013). It also encompasses the practices that are enacted in a given place enabled and constrained by the structural features of that place. Although individuals may be unaware that by acting in a certain way they are producing/reproducing the structure that enabled them to act in that way, they are able to maintain control over the motives that prompted their action, and to maintain an understanding of their behaviour and of that enacted by others. Culture can thus be analysed in terms of structures (of signification, legitimation and domination) and by the prevalence of one of these structures over action. For example, in some places structures of legitimation can be more prevalent than in others in which sanctioning aspects in interaction are less influential. In others, structures of signification - for example the hierarchical distance that characterizes class division can be particularly resilient, affecting both collective dynamics, e.g. the way in which social shifts take place, and individual relationships, e.g. the possibility for a person to establish social relations and acquire legitimate access and acceptance in higher social strata.

Structuration theory can also explain place identity and its relationship with culture. As far as identity is concerned, Giddens' theory stresses a conception of social identity which is the result of the interplay between the individual's identity in society and the society in the self. Identity and social structure are continually mingled, created and recreated through the intertwining of dominant institutional projects, individual biographies and the structural properties of the social context. For Giddens, identity is 'implanted' in agents by their membership of a collective and the traits constructed by a specific culture that leads it toward specific social conducts. When agents see themselves as culturally bonded to a collective, this will be reflected in their self-identity and their level of participation in institutional projects (Campelo et al., 2013). It may even result in feelings of place attachment (Altman and Low, 1992). Individuals' identities are also built by their need to perceive themselves as linked with the social identity of a group, i.e. to consider themselves as active participants in place identity formation (Ashforth and Mael, 1989). Thus, as Giddens (1991) stated, identity can be considered a project involving a continuous interplay among the self, the collective, and the place's structural properties. 
Regarding place image, for Giddens, the structural properties possessed by a given place are the main elements to which agents refer to make sense of that place. Thus, these structural properties routinized and instantiated in action - constitute the main elements upon which stakeholders (whether natives or visitors) form their perceptions and images of a place, contributing to further institutionalizing those properties and the actions that they enable and constrain.

This means that culture, identity and image are linked by practices and by the recognition of practices enacted within a given place. Place culture does not exist as such but is brought into being by actors' practices enabled and constrained by structures of signification, legitimation and domination. Culture contributes to shaping both individual and collective identity, which are indissolubly interrelated and made concrete in individual biographies and institutional dominant projects. Identity is subject to a process of institutionalization through reflexive monitoring, theoretical understanding and motivation of action. Image, in its turn, is reflected in structural properties of a given place that enable stakeholders to distinguish that place from others and to make sense of the interactions occurring within it.

The above structurationist approach underlines that the interplay between culture, identity and image occurs through (individual and collective) practices that both shape and are shaped by the wider structures constituting the place. Given that the place brand is formed through this interplay (Kavaratzis and Hatch, 2013), it becomes evident that the place brand is constituted, enacted and made meaningful by means of peoples' everyday practices. The place brand only pre-exists peoples' actions as a frame that implies the structures to which to refer when people interpret it and put it to their own use, which in turn re-shapes the frame of these structures. Differently stated, the practices of people that facilitate the interplay between place culture, place identity and place image are the same practices that form the place brand. At the same time, the place brand as the wider frame of the culture-identity-image interplay shapes how people act within this frame, and how they interpret the culture of the place, its identity and its image. Thus, the place brand itself becomes a 
structure that shapes peoples' agency, becoming a vehicle that helps people to understand the place and form a relationship with it.

Kavaratzis and Hutch's (2013) dynamics of place brands and the four sub-processes that link culture, identity and image can hence be reframed as depicted in Figure 3.

In the following sections, we use two illustrative examples to show how structuration theory advances understanding of place branding. To be noted is that cases are used as practical illustrations to support the theoretical and empirical relevance and plausibility of arguments proposed and to illustrate the operation of the underlying mechanisms (Siggelkow, 2007). Thus, they should not be taken to be empirical attempts to validate the argument proposed, but rather illustrations of how structuration theory and its focus on the recursive interplay between action and structure that makes up place culture, place identity and place image can advance the current understanding of the place branding process and foster a practice-oriented approach to the study of place brands.

\section{- Figure 3 around here -}

\section{Structuration at the strategic level: Sustainability as a place branding strategy for Stockholm}

The first example concerns the broad, strategic level of place branding, i.e. the process of designing the positioning of the place brand by focusing on the identification and exploitation of a brand value that can be leveraged to bestow the brand with a distinctive or unique positioning (Kotler and Gertner, 2002). This is a process that in place branding practice is often driven by a top-down approach guided by public administrators and materialized in a narrow-scope set of communication tactics to appeal to external stakeholders (Hudson et al., 2016). It is less often deployed to seek the involvement and consensus of local citizens (Zenker et al., 2017).

The illustrative example that we propose relates to sustainability, a value that place branders can pursue (Middleton and Hawkins, 1998) and that involves public administrators, companies and the 
society at large (Dryzek, 2013). A growing number of place branders are attempting to position places as 'sustainable' (Braun et al. 2013; Andersson and James, 2018; Gatrell et al., 2018) since sustainability has proven to be of paramount importance for both resident and non-resident brand recipients (Merrilees et al., 2009).

Sustainability - as a value that may guide the strategic development of a place brand - is well suited to illustrating structuration theory in context because sustainability is closely bound up with the behaviours that individuals enact within a given place, and it is formalized as institutional projects pursued by many public administrators (Spaargaren, 2003). Sustainability, therefore, cannot be seen as a natural quality of people, places or brands. For example, the morphological qualities of a country like Finland allow the national tourism office to brand the country as the 'Land of a thousand lakes' independently from any individual and collective effort. Rather, sustainability is a guide to conduct, reflected in practices 'designed' by public administrators, rooted in both individual and social identity, and reflected in people's routinized practices. These practices reflect cultural traits that, once enacted, become the means through which the sustainable place is created, the place identity is shaped, and the image is projected to external stakeholders.

Framed in this way, sustainability goes far beyond institutional claims and assumes a practical meaning. Thus, the claim of being sustainable is not sufficient to brand the place as such if the relevant practices are not enacted and are not visible to stakeholders. Moreover, being sustainable is somehow a place value that by its very nature is developmental, i.e. always 'in becoming' because it requires a continuous, ongoing and routinized commitment by people to keep the brand value consistent across time. For this reason, structuration theory is well suited to explaining how sustainability becomes the main constituent of the place brand, how it is maintained, and how it evolves throughout the passing of time.

An example of the successful strategic use of sustainability as a core brand value is provided by the City of Stockholm, which, owing to its constant effort and commitment to place sustainability at the top of its political agenda, was awarded the prestigious title of European Green Capital in 2010. 
According to Stockholm's Final Report (Final Report, 2015), this goal was achieved thanks to the dominance of sustainability issues on the city's political agenda, and to the successful involvement of citizens in the sustainable objectives fulfilled. As the jury that awarded the Swedish capital commented (Final Report, 2015):

'Stockholm has an outstanding, long historical track record of integrated urban management also confirmed by its ongoing credible green credentials. Ambitious plans for the future clearly demonstrate continuity' (p. 5).

Sustainability has long been a strategic priority for the city of Stockholm. The Swedish capital hosted the first conference of the United Nations on the environment in 1972, and already back in the mid-20th century investments were made to find efficient and new solutions to create a modern city, such as the design of an integrated metro system to discourage the use of private cars, the implementation of a district-based heating system, and the building of an infrastructural system designed to avoid traffic congestion in the city (Mertzger and Olsson, 2013). Furthermore, and most importantly, from the outset the fulfilment of sustainable goals for the city of Stockholm has been envisioned as requiring the involvement of citizens (see Mineur, 2007): back in 1997, the citizens of Stockholm were invited by the office of the municipality to discuss and define sustainability indicators from their own perspective. A campaign was launched via leaflets on public transport and via a website to collect citizens' suggestions and preferences of what they wanted to be included as sustainable priorities for the city. More than 11,000 ideas and suggestions were received from the public. They were sorted by the office into a set of indicators (named 'Stockholmarnas indikatorer för hållbar utveckling', i.e. the People of Stockholm's Indicators for Sustainable Development') defining the most important issues related to sustainability to deal work with and setting the actionplan template that citizens and public administrators had to follow. As Mineur (2007) argues, these sustainable indicators were conceived primarily as tools to stimulate citizens' actions, to make the public feel engaged and committed to their fulfilment, and to influence citizens by creating a sense of responsibility at the individual level. 
As regards the involvement of citizens, Stockholm's Final Report (Final Report, 2015) states:

'One challenge was to find ways to make the people of Stockholm aware of the award and proud of it. The Stockholmers were already heavily committed to the city's environmental work but were not aware of the European Green Capital Award' (p.7).

What emerges from the above quote is that the individual biographies of citizens of Stockholm are aligned with the institutional project of its public administrators and vice versa. Thus, being 'sustainable' is salient for both Stockholmers' individual and collective identity. The challenge for public administrators was not to induce Stockholmers to act sustainably but rather to make them aware of the award, and to commit them to the collective achievements necessary to win the prize. Put differently, the challenge was to push citizens to become aware of the existence of a brand, and to stimulate them to become active participants in the place branding process, and let them take part in the co-creation of the brand.

Commenting on the results obtained five years after winning the prize, the executive office of the city of Stockholm wrote in its Final Report (2015):

'The City of Stockholm strives to incorporate sustainability into every aspect of the city life, but to come all the way, it is necessary to have the Stockholmers on board. And they are! The citizens of Stockholm are deeply involved in their city. Nine out of ten believe it is important to have a long-term strategy for Stockholm's development. Seven out of ten are interested in environmental issues and believe the city should impose strict requirements on its residents with regards to environmentally friendly living. Eight out of ten use and are satisfied with the public transport system in rush hour' (p. 16).

The title of European Green Capital heightened the commitment of Stockholmers to the environment even further, as it is reported that:

' $30 \%$ of Stockholmers think it is more important for them to do their bit for a better environment since Stockholm was declared European Green Capital' (p. 41).

The place brand thus became a cultural referent (i.e. a structure) that induced people to act differently, converting them into active participants in the branding process. Turning citizens into active participants in the place branding process hence stimulated citizens to act 'on behalf' of the 
brand, prompting its structuration, and making it a guide of conduct for both individuals and collective actors. As the report states:

'Sustainability enhances the Stockholm brand. Being named the first European Green Capital is a fantastic acknowledgement of Stockholm's long-term efforts and future ambitions (...). The award is now clearly an integrated part of our brand (...) (p. 17).

What vividly emerges from the above-reported illustrative example of Stockholm is that the development of a place brand around a core value that hinges on enacted practices (like sustainability) cannot be effectively realized without seeking and exploiting the proactive involvement of citizens in its concretization. The strategy of developing the place brand cannot be devised as a top-down agenda designed by public administrators where some strategic objectives are imposed on citizens. Rather, the place branding strategy must be pursued with the involvement of internal stakeholders by letting them take part in definition of the strategic objectives to fulfil, and by making them aware that fulfilment of these objectives is largely owed to their practices. If this is done, the creation of the place brand emerges as an 'objectification' of a set of routinized behaviours that form the basic elements upon which the place brand is built, able to guide (more or less reflexively) how people's agency should be deployed to guarantee the brand's survival in the long term. The structure (the sustainable place brand) thus becomes such because it guides actors to act in a sustainable way and to adjust their behaviour accordingly. It forms the basis for enacting the reflexive monitoring of action, i.e. monitoring their actions and those of others to evaluate whether or not behaviours are aligned with the brand's value, because it makes it possible to maintain a continuous understanding of their actions and that of others (rationalization of actors) and because it pushes people to act purposefully to safeguard and maintain the brand and its value (motivation of action). The role that public administrators have to play is to enforce certain structures, e.g. structures of legitimation and of domination to sanction behaviours that are not aligned with the core brand value, for example by imposing harsher sanctions for non-compliance with environmentally friendly actions, while favouring every other behaviour that is intentionally and 


\section{Structuration at the tactical level: North Dakota's controversial poster}

The second illustrative example concerns a tactical activity, namely a promotional poster and the reactions that it provoked in social media, issued in the city of Fargo, the largest city in North Dakota located on the banks of the Red River. The poster was intended to promote and enhance the city's image as a nightlife-friendly place. The example is used here to illustrate how the development of a place brand that is to some extent detached from the practical culture of the place and to the constitutive elements of its identity can lead to bad execution of place branding initiatives. The poster (Figure 4) showed two men and three women flirting in a bar and the slogan read 'Drinks, dinner, decisions. Arrive a guest. Leave a legend'. The promotional poster was one of a series of images developed by the city's tourism division that included others: for instance, ones showing couples shopping and hiking, and another showing a pair of men playing golf. It was meant to be 'a little flirty, a little fun,' declared Pat Finken, president of Odney Advertising, the agency that created the ad, to a journalist of the Daily Mail (2012).

\section{- Figure 4 around here-}

Once posted on social media, the ad quickly drew criticism, and many viewers, outraged by the sexual connotation, called it a campaign failure, 'sickening', 'racy' and 'inappropriate' (Johanson, 
2012). The public's reaction brought extensive local, national and even international media attention and soon after its release, the state's tourism division decided to pull the ad from the Facebook page and remove it from a digital version of the visitors' guide for 2012 (Kim, 2012). The director of North Dakota's tourism division explained to the Associated Press that the ad was pulled due to the number of negative comments on social media.

A practice that is presumably part of life in Fargo (i.e. flirting) was used in a way that did not appeal to a certain part of the audience (i.e. residents) although the ad was created to appeal to a different target audience (i.e. potential visitors). Sara Otte Coleman, director of North Dakota's tourism division, declared to the International Business Times, 'North Dakota has branded itself as "Legendary" for over a decade and tourism officials hoped to branch out from the traditional images of North Dakota as a destination only for nature-lovers.' Thus, what the tourism division intended with the promotional poster was to project an image of North Dakota that could attract a different target of visitors. In the words of Coleman 'the ad was never meant for a U.S. audience. It was actually created to draw Canadians down to the state for a fun weekend getaway.' (Johanson, 2012)

For the critics, the practice of 'flirting' should not be considered a constituent of the local identity and therefore should not be used to project an image. The individuals who enacted their objections to the ad by posting negative comments and complaints managed through this practice to bring about change in the social structure that allowed them to enact their practice in the first place. If the tourism division had not put the posters on Facebook or had prevented feedbacks (for example by limiting the exposure of the poster to its desired target, i.e. prospective Canadian visitors), then arguably the critics would not have been able to complain in such a way. Thus, the structure that implied the particular practice as an element of Fargo's identity was actually re-shaped by the action of the critics, demonstrating that individual power can indeed bring about institutional change. However, this change only became such when the action of the critics was institutionalized by the structure itself (i.e. when the tourism division pulled the ad) producing as an (unintentional) 
effect the reinforcement of North Dakota's cultural traits as the place in which some practices despite existing are not deemed appropriate to be communicated to shape a different place image. It is also interesting to observe the pathway of change.

What started as a reaction to a structure of signification (dislike of what the poster implied), was transformed first into a structure of legitimation (the complaint deeming the poster unacceptable and demanding the 'sanction' of withdrawing it) and, when institutionalized, further transformed it into a structure of domination (the withdrawal of the poster although other groups might have liked it).

Even after the ad was pulled, comments from North Dakotans and others continued to pour in to Facebook and comment platforms of the news websites that reported the story. Although some commented negatively on the ad by attacking the models featured in the poster (see Appendix A where comments from $\mathrm{ABC}$ and from the Daily Mail platform are reported), others condemned the act of pulling the ad and 'giving in to the critics'. Commentator Ben commented on the ABC platform:

'Do these same people have a problem with the Vegas ads? I can't believe people are actually upset with this ad. There is nothing vulgar or inappropriate about it. The only thing that upsets me is the fact that the Tourism Board bowed to the infinite minority complaining about this and pulled the ad. STOP GIVING IN TO THESE PEOPLE!!!'

So Ben is actually insulted by the institutionalization of the critics' act and the fact that it became a structure of domination. Fargo resident Katherine Paynter, who took part as a model featured in the accused promotional poster, commented to the Associated Press (Daily Mail, 2012),

'When they posted it on Facebook for the public to view I thought nothing of it, nothing at all. They're trying to get a certain age group to look into the nightlife in North Dakota (...). It wasn't supposed to be some sleazy, racy photo.'

What she is saying here is that the practice depicted in the poster is actually a real practice occurring in the place and there is nothing wrong with highlighting it. Lawrence, also a resident of Fargo, commenting on the Daily Mail's (2012) platform said: 
'I really don't see what the noise is about honestly. ... It looked very innocent. This is even more conservative as compared to what you see at night. [...] These people know how to have fun.'

Another commentator (Megan) was supportive of the ad and explicitly and positively commended the attempt of the tourism division to try to establish a different image of North Dakota toward a non-local audience. She wrote:

'How long do residents really want to perpetuate the belief that North Dakota women still wear wool petticoats and don't leave the kitchen? I think the nightlife ad was great.'

So, again we have both residents who agreed that the practice depicted was indeed part of the place's identity, and others who found value in the ad's attempt to project a new/different image of the place compared to the one which was largely institutionalized. It is obvious that some commentators saw their individual biographies as intertwined with the wider structure of Fargo as a place for nightlife, entertainment and flirting, and this allowed them to accept the institutional project of enacting the specific element of place identity (i.e. the tourism division's promotional poster). Others instead, i.e. those that condemned the poster, did not see themselves and their individual biographies as properly represented in the communication campaign and fell insulted by it. The dialectic debate that divided North Dakotans into the group of supporters of Fargo's image as the city of 'flirting' and the group of those that opposed the idea of depicting the city as such, suggests that the practice of flirting in Fargo has some sort of sub-cultural overtone and that it is somehow in contrast with the institutionalized and taken-for-granted cultural traits of the place. What was conceived as a 'a little flirty, a little fun' promotional poster became the terrain of dispute between promoters of a new place image more attuned to an evolving place identity, and those that instead assumed a more conservative stance and obstructed the process of emancipation of the place identity toward a more 'sophisticated' image. The act of pulling the ad by the tourism division was thus more than a reaction to address the discontent of those that found the campaign 'sickening'. The act of pulling produced the unintended outcome, of reinforcing some cultural traits of the place 
(a latent righteousness of locals that see flirting as an inappropriate act) that inevitably led some recipients to (re)affirm a largely institutionalized idea of the place image. Peter, commenting on the ABC News's comments platform, captured extremely well how the act of pulling the ad affected this dynamic:

'For years I thought North Dakota had very little to offer, so I did not visit. When I saw this ad, I thought it looked mildly sophisticated and an interesting place to visit. Now that I've seen the reaction in North Dakota, I've decided I was right in the first place and I don't need to go. Seems a little backward there, don't you think?'

\section{Conclusion and implications}

This paper has proposed a structuration-based conceptualisation of place brands which has significant implications for place branding theory and practice. The main implication that can be drawn from the theory itself and from the two illustrative examples reported is that the place brand and place branding processes are practical in nature. The place brand is constituted by the interplay of culture, identity and image as they are performed in actions and practices. Therefore, place branding claims need to refer either to practices that are already part of the cultural repertoire of the place and constitute its identity, or to prospective practices that will be enacted by locals and/or other stakeholders as part of the place's (projected) identity and culture. If the focus of specific place branding activities is on this second type of claims, then it is clearly necessary to first enable and facilitate the enactment of relevant practices within the place and only afterwards attempt to brand these to others. In alternative, to make the enactment of these practices by people living in a certain place on top of the institutional projects set up by public decision makers. This is facilitated if political actors can rely on structures of legitimation and domination to favour the convergence of individuals' behaviour with such dominant projects. The second major implication is that purely externally oriented messages and campaigns are best avoided. The example of the city of Fargo vividly shows that 'selling' a place brand by focusing on practices designed only to appeal to external audiences while not taking sufficient account of how this affects internal stakeholders may lead to brand communication failures. However, despite the negative consequences that bad 
communication about the place brand may have for internal stakeholders and also for external audiences (primarily the media), failed communication tactics have the paradoxical effect of positively affecting the process of structuration of the place brand and its features, both reinforcing the structure of the place brand anchored to its culture and identity, and making citizens more aware about the existence of the place brand and of its connection to the identity, and place branders more conscious that every attempt to communicate the brand has to be closely aligned with institutionalized practices that shape the place's culture and identity.

A practice approach indicates how the distinction between external and internal audiences and, therefore, the distinction between identity and image is only analytical. It is the same set of practices that constitute both image and identity. This also means that there can be no such thing as a message that only reaches external audiences, because internal and external are actually inseparable. Therefore, place branding activities need to account for this inseparability and be designed accordingly. Both these implications direct attention to a third one, i.e. the fact that local populations are crucial for place branding because they shape the meanings that the place brand comes to assume through their practices. A structuration approach highlights the central role that residents play in branding the place through their own interpretations of the place and its brand, through their actions in which they enact practices that legitimate or reject the place brand and through their interactions with visitors and other outsiders but also with each other. In particular, the effective intertwining of institutional projects and individual biographies is a necessary precondition for the place brand to become meaningful for both residents and strangers. The example of Stockholm shows that the Green Capital award was not simply the result of sustainable political programmes, but rather was the result of the fulfilment of these programmes achieved through active participation of citizens that, by behaving in a 'green' way enacted their identity as Stockholmers. Of course, the mutual co-existence of dominant institutional projects and individual biographies is not always free from disputes, controversies, and resistances. The North Dakota example shows very vividly that place branding activities are subject to a process of meaning 
negotiation involving a plethora of stakeholders and a multitude of individual biographies that in some cases can align with and in others clash with the institutional project pursued. However, while this concept seems to be widely acknowledged in the current branding literature, the application of structuration theory (and of other practice theories) offers several theoretical hints to inspire a wide array of empirical efforts aimed at showing how this social construction actually takes place. A promising line of research consists in conducting longitudinal studies of place branding development grounded on structuration theory. As Miles (2012) suggested, in order to apply structuration theory in empirical research, two types of analysis can/should be conducted: strategic conduct analysis and institutional analysis. The former involves exploring how various practices are routinized within a given social context and - as such - have the power to affect individuals' interaction at different societal levels, i.e. in face-to-face dyadic encounters as well as in broader relational circles. The latter, is instead fruitful for investigation of what are the routinized features of a given social context that favor or inhibit the establishment of a place brand that is meaningful for both residents and strangers. Institutional analysis involves exploring how structures of signification, domination, and legitimation influence each other, and the interaction and practice pattern enacted by individuals. In particular, historical institutional analysis can help researchers to understand the process by which structures of a certain place emerged, consolidated and eventually changed over time and formed the features of the place brand. Comparative institutional analysis instead can be used to compare different places and identify the factors that have determined similar or different evolutionary patterns responsible for making place branding simpler or more challenging than the same practice enacted in other places.

A second line of research concerns further theoretical efforts aimed at providing other critical accounts of how other practice theorists can inform our understanding of the place branding process and of the practical connection betwen place culture, identity and image. For example, the Bourdieusian conceptualization of power can be fruitfully applied to shed light on the antagonistic practices enacted to resist eventual institutional projects that do not fit with the place's culture and 
identity and, as such, generate social disputes. We see great potential in applying Bourdieu's theory of practice to gain better understanding of those place branding strategies that - once enacted generate fierce opposition by internal stakeholders, as exemplified by Hamburg after the city's attempt to brand itself as the city of creativity and the subsequent birth of the 'Not in Our Name' antagonistic movement.

\section{References}

Aitken, R. and Campelo, A. (2011), "The four Rs of place branding”, Journal of Marketing Management, Vol. 27 No. 9/10, pp. 913-933.

Altman, I. and Low, S. (1992), Place Attachment. Plenum, New York.

Andersson, I. and James, L. (2018), "Altruism or entrepreneurialism? The co-evolution of green place branding and policy tourism in Växjö, Sweden”, Urban Studies, DOI: 10.1177/0042098017749471 (in press).

Anholt, S. (2010), "Definitions of place branding-Working towards a resolution", Place Branding and Public Diplomacy, Vol. 6 No. 1, pp. 1-10.

Archer. M.S. (1982), "Morphogenesis versus structuration: on combining structure and action", The British Journal of Sociology, Vol. 33 No. 4, pp. 455-483.

Ashforth, B.E. and Mael, F. (1989), "Social identity theory and the organization", Academy of Management Review, Vol. 14 No. 1, pp. 20-39.

Ashworth, G.J. and Kavaratzis, M. (2009), "Beyond the logo: Brand management for cities", Journal of Brand Management, Vol. 16 No. 8, pp. 520-531.

Ashworth, G.J., Kavaratzis, M. and Warnaby, G. (2015), "The need to rethink place branding”, in Kavaratzis, M., Ashworth, G.J. and Warnaby, G. (Eds), Rethinking Place Branding, Springer, Cham, pp. 1-11.

Askegaard, S. (2006), "Brands as a global ideoscape", in Schroeder, J. and Salzer-Mörling, M. (Eds.), Brand Culture, Routledge, London, pp. 91-102.

Askegaard, S. and Kjeldgaard, D. (2007), "Here, there, and everywhere: Place branding and gastronomical globalization in a macromarketing perspective". Journal of Macromarketing, Vol. 27 No. 2, pp. 138-147.

Askegaard, S. and Linnet, J.T. (2011), "Towards an epistemology of consumer culture theory. Phenomenology and the context of context", Marketing Theory, Vol. 11 No. 4, pp. 381-404.

Bourdieu, P. (1977), Outline of a Theory of Practice (Vol. 16), Cambridge University Press, Cambridge.

Bourdieu, P. (1994), "Structures, habitus, power: Basis for a theory of symbolic power" in Dirks, N.B., Eley, G. and Ortner, S.B. (Eds.), Culture/Power/History: A Reader in Contemporary Social Theory, Princeton University Press, Princeton, pp. 155-199.

Braun, E. (2012), "Putting city branding into practice", Journal of Brand Management, Vol. 19 No. 4, pp. 257-267.

Braun, E., Kavaratzis, M. and Zenker, S. (2013), "My city-my brand: the different roles of residents in place branding", Journal of Place Management and Development, Vol. 6 No. 1, pp. 1828.

Calhoun, C., LiPuma, E. and Postone, M. (1993), Bourdieu. Critical Perspectives. Chicago University Press, Chicago.

Cayla, J. and Eckhardt, G.M. (2008), "Asian brands and the shaping of a transnational imagined community”, Journal of Consumer Research, Vol. 35 No. 2, pp. 216-230. 
Cayla, J. and Arnould, E.J. (2008), "A cultural approach to branding in the global marketplace”, Journal of International Marketing, Vol. 16 No. 4, pp. 86-112.

Campelo, A., Aitken, R., Thyne, M. and Gnoth, J. (2013), "Sense of place: The importance for destination branding", Journal of Travel Research, Vol. 53 No. 2, pp. 154-166.

Clegg, S.R. (1989), Frameworks of power. Sage Publisher, London.

Colomb, C. (2012), "Pushing the urban frontier: temporary uses of space, city marketing, and the creative city discourse in 2000s Berlin", Journal of Urban Affairs, Vol. 34 No. 2, pp. 131152.

Cresswell, T. (2004), Place: a short introduction. Blackwell, Malden.

Daily Mail (2012). 'Arrive a guest... Leave a legend': 'Sexist' North Dakota tourism board advert pulled for being too sleazy, Daily Mail, January 17, available at: http://www.dailymail.co.uk/news/article-2087621/Sexist-North-Dakota-tourism-board-advertpulled-sleazy.html\#comments

Dryzek, J.S. (2013), The Politics of the Earth: Environmental Discourses. Oxford University Press, Oxford.

Escobar, A. (2001), "Culture sits in places: reflections on globalism and subaltern strategies of localization”, Political Geography, Vol. 20 No. 2, pp. 139-174.

Eshuis, J., Braun, E. and Klijn, E.H. (2013), "Place marketing as governance strategy: An assessment of obstacles in place marketing and their effects on attracting target groups", Public Administration Review, Vol. 73 No. 3, pp. 507-516.

Everts, J., Lahr, M. and Watson, M. (2011), "Theories of practice and geography", Erdkunde, Vol. 65 No. 4, pp. 323-334.

Feldman, M.S. and Orlikowski, W.J. (2011), "Theorizing practice and practicing theory", Organization Science, Vol. 22 No. 5, pp. 1240-1253.

Fournier, S. (1998), "Consumers and their brands: Developing relationship theory in consumer research", Journal of Consumer Research, Vol. 24 no. 4, pp. 343-373.

Final Report (2015), Stockholm: The First European Green Capital. City of Stockholm Executive Office. Press.

Fligstein, N. and McAdam, D. (2012), A theory of fields, New York, Oxford University

Gardner, B.B. and Levy, S.J. (1955), "The product and the brand", Harvard Business Review, Vol. 33 No. 2, pp. 33-39.

Gatrell, J., Reid, N. and Steiger, T. L. (2018), "Branding spaces: Place, region, sustainability and the American craft beer industry", Applied Geography, Vol. 90, pp. 360-370.

Gertner, D. (2011), "Unfolding and configuring two decades of research and publications on place marketing and place branding”, Place Branding and Public Diplomacy, Vol. 7 No. 2, pp. 91106.

Giddens, A. (1979), Central Problems in Social Theory: Action, Structure and Contradiction in Social Analysis. Macmillan, London. London.

Giddens, A. (1981), A Contemporary Critique of Historical Materialism. Macmillan,

Giddens, A. (1984), The Constitution of Society. Outline of the Structuration Theory, Polity Press, Cambridge.

Giddens, A. (1986), "Action, subjectivity, and the constitution of meaning", Social Research, Vol. 53 No. 3, pp. 529-545.

Giddens, A. (1991), Modernity and Self-Identity: Self and Society in the Late Modern Age, Stanford University Press, Stanford.

Govers, R. and Go, F. (2009), Place Branding: Virtual and Physical Identities, Glocal, Imagined and Experienced. Palgrave-Macmillan, Basingstoke. 
Greenberg, M. (2008), Branding New York. How a City in Crisis Was Sold to the World, Routledge, London.

Gupta, A. and Ferguson, J. (1992), "Beyond 'culture': Space, identity, and the politics of difference", Cultural Anthropology, Vol. 7 No. 1, pp. 6-23.

Gupta, S., Foroudi, M. M., Väätänen, J., Gupta, S. and Wright, L. T. (2018), "Nations as brands: Cinema's place in the branding role", Journal of Business Research (in press) DOI: 10.1016/j.jbusres.2018.02.017.

Hankinson, G. (2005), "Destination brand images: a business tourism perspective", Journal of Services Marketing, Vol. 19 No. 1, pp. 24-32.

Harrison, S. and Dourish, P. (1996), "Re-place-ing space: the roles of place and space in collaborative systems", in Proceedings of the 1996 ACM Conference on Computer Supported Cooperative Work, pp. 67-76.

Haslett, B. B. (2013), Communicating and organizing in context: The theory of structurational interaction, New York, Routledge.

Hatch, M.J. and Schultz, M. (2002), "The dynamics of organizational identity", Human Relations, Vol. 55 No. 8, pp. 989-1018.

Hatch, M.J. and Schultz, M. (2010), "Toward a theory of brand co-creation with implications for brand governance", Journal of Brand Management, Vol. 17 No. 8, pp. 590-604.

Houghton, J.P. and Stevens, A. (2010), "City branding and stakeholder engagement", in Dinnie, K. (Ed.), City Branding: Theory and Cases, Palgrave-McMillan, Basingstoke, pp. 45-53.

Hudson, S., Cárdenas, D., Meng, F. and Thal, K. (2017), "Building a place brand from the bottom up: A case study from the United States", Journal of Vacation Marketing, Vol. 23 No. 4, pp. 365-377.

Ind, N. and Coates, N. (2013), "The meanings of co-creation", European Business Review, Vol. 25 No. 1, pp. 86-95.

Jenkins, R. (1982), "Pierre Bourdieu and the reproduction of determinism", Sociology, Vol. 16 No. 2, pp. $270-281$.

Johanson, M. (2012), "North Dakota's 'Racy' Tourism Ad: 'Legendary' or an Epic Fail?" International Business Times, January 17, Available at: http://www.ibtimes.com/north-dakotasracy-tourism-ad-legendary-or-epic-fail-396828

Jones, R. and Fowler, C. (2007), "Placing and scaling the nation", Environment and Planning D: Society and Space, Vol. 25 No. 2, pp. 332-354.

Kalandides, A. (2011), "City marketing for Bogotá: a case study in integrated place branding”, Journal of Place Management and Development, Vol. 4 No. 3, pp. 282-291.

Karababa, E. and Ger, G. (2011), "Early modern Ottoman coffeehouse culture and the formation of the consumer subject", Journal of Consumer Research, Vol. 37 No. 5, pp. 737-760.

Kavaratzis, M. (2004), "From city marketing to city branding: Towards a theoretical framework for developing city brands", Place Branding, Vol. 1 No. 1, pp. 58-73.

Kavaratzis, M. and Hatch, M.J. (2013), "The dynamics of place brands: an identity-based approach to place branding theory”, Marketing Theory, Vol. 13 No. 1, pp. 69-86.

Kavaratzis, M. and Kalandides, A. (2015), "Rethinking the place brand: the interactive formation of place brands and the role of participatory place branding", Environment and Planning $A$, Vol. 47 No. 6, pp. 1368-1382.

Kavaratzis, M. and Ashworth, G. (2015), "Hijacking culture: the disconnection between place culture and place brands", Town Planning Review, Vol. 86 No. 2, pp. 155-176.

Kavaratzis, M. (2017), "The participatory place branding process for tourism: linking visitors and residents through the city brand" in Bellini, N. and Pasquinelli, C. (Eds.), Tourism in the City, Springer International Publishing, pp. 93-107.

Kim, S. (2012), "North Dakota Tourism Ad Too Racy for Some". ABC News, January 17, Available at: http://abcnews.go.com/blogs/business/2012/01/north-dakota-tourism-too-racy-for-some/ 
King, A. (2000), "Thinking with Bourdieu against Bourdieu: A 'practical' critique of the habitus", Sociological Theory, Vol. 18 No. 3, pp. 417-433.

Kornberger, M. (2010), Brand society: How brands transform management and lifestyle, Cambridge, Cambridge University Press.

Kotler, P. and Gertner, D. (2004), "Country as brand, product and beyond: A place marketing and brand management perspective" in Morgan, N., Pritchard, A. and Pride, R. (Eds), Destination Branding: Creating the Unique Destination Proposition (second edition), Elsevier Butterworth-Heinemann, Burlington, pp. 40-56.

Kravets, O. (2012), "Russia's "Pure Spirit" Vodka Branding and Its Politics", Journal of Macromarketing, Vol. 32 No. 4, pp. 361-376.

Kuenzel, S. and Vaux Halliday, S. (2008), "Investigating antecedents and consequences of brand identification", Journal of Product \& Brand Management, Vol. 17 No. 5, pp. 293-304.

Lizardo, O. (2010), "Beyond the antinomies of structure: Levi-Strauss, Giddens, Bourdieu, and Sewell”, Theory and Society, Vol. 39 No. 6, pp. 651-688.

Lucarelli, A. (2018), "Place branding as urban policy: the (im)political place branding", Cities, Vol. 80, pp. 12-21.

Lury, C. (2004), Brands: The Logos of the Global Economy. London, Routledge.

Mayes, R. (2008), "A place in the sun: The politics of place, identity and branding", Place Branding and Public Diplomacy, Vol. 4 No. 2, pp. 124-135.

Medway, D. and Warnaby, G. (2014), "What's in a name? Place branding and toponymic commodification", Environment and Planning A, Vol. 46 No. 1, pp. 153-167.

Merrilees, B., Miller, D. and Herington, C. (2009), “Antecedents of residents' city brand attitudes", Journal of Business Research, Vol. 62 No. 3, pp. 362-367.

Merz, M.A., He, Y. and Vargo, S.L. (2009), "The evolving brand logic: a service-dominant logic perspective", Journal of the Academy of Marketing Science, Vol. 37 No. 3, pp. 328-344.

Mertzger, J. and Olsson, A.R. (2013), "Introduction: the greenest city?" in Mertzger, J. and Olsson, A.R. (Eds.), Sustainable Stockholm: Exploring Urban Sustainability in Europe's Greenest City. Routledge, New York, pp. 1-9.

Middleton, V.T.C. and Hawkins, R. (1998), Sustainable Tourism: A Marketing Perspective, Butterworth-Heinemann, Oxford.

Miles, J.A. (2012), Management and Organization Theory: A Jossey-Bass Reader (Vol. 9). John Wiley and Sons, San Francisco.

Mineur, E. (2007), Towards Sustainable Development: Indicators as a tool of local governanceì, Research Report of the Department of Political Science, Umeå University, Sweden.

Moilanen, T. and Rainisto, S. (2009), How to Brand Nations, Cities and Destinations: A Planning Book for Place Branding, Palgrave-McMillan, Basingstoke.

Morgan, N.J., Pritchard, A. and Piggott, R. (2003), "Destination branding and the role of the stakeholders: The case of New Zealand", Journal of Vacation Marketing, Vol. 9 No. 3, pp. 285-299.

Mouzelis, N. (1995), Sociological Theory: What Went Wrong? Diagnosis and Remedies, Routledge, London.

Navarro, Z. (2006), "In search of a cultural interpretation of power: the contribution of Pierre Bourdieu”, IDS Bulletin, Vol. 37 No. 6, pp. 11-22.

NION, Brand Hamburg (2010), "Not in our name! Jamming the gentrification machine: a manifesto", City, Vol. 14 No. 3, pp. 323-325.

Papadopoulos, N. (2004), "Place branding: Evolution, meaning and implications", Place Branding, Vol. 1 No. 1, pp. 36-49.

Parkerson, B. (2007), "From schlock to hot: Shifting perceptions of Brooklyn", Place Branding and Public Diplomacy, Vol. 3 No. 4, pp. 263-267.

Pasquinelli, C. and Teräs, J. (2013), "Branding knowledge intensive regions: A comparative study of Pisa and Oulu high-tech brands", European Planning Studies, Vol. 21 No. 10, pp. 16111629. 
Pred, A. (1983), "Structuration and place: on the becoming of sense of place and structure of feeling", Journal for the Theory of Social Behavior, Vol. 13 No. 1, pp. 45-68.

Pred, A. (1984), "Place as historically contingent process: structuration and the timegeography of becoming places", Annals of the Association of American Geographers, Vol. 74 No. 2, pp. 279-297.

Reckwitz, A. (2002), "Toward a theory of social practices a development in culturalist theorizing", European Journal of Social Theory, Vol. 5 No. 2, pp. 243-263.

Ritchie, J.R.B. and Ritchie, R.J.B. (1998), "The branding of tourism destinations: past achievements and future challenges" in Keller, P. (Ed.), Proceedings of the 1998 Annual Congress of the International Association of Scientific Experts in Tourism, Destination Marketing: Scopes and Limitations. Marrakech, Morocco, pp. 89-116).

Rojas-Méndez, J. (2013), "The nation brand molecule", Journal of Product \& Brand Management, Vol. 22 No. 7, pp. 462-472.

Rojas-Méndez, J. I., Papadopoulos, N. and Alwan, M. (2015), "Testing self-congruity theory in the context of nation brand personality", Journal of Product \& Brand Management, Vol. 24 No. 1, pp. 18-27.

Schatzki, T.R. (1987), "Overdue analysis of Bourdieu's theory of practice”, Inquiry, Vol. 30 No. 1-2, pp. 113-135.

Schatzki, T.R. (1996), Social Practices: A Wittgensteinian Approach to Human Activity and the Social, Cambridge University Press, Cambridge.

Schatzki, T.R. (1997), "Practices and actions: a Wittgensteinian critique of Bourdieu and Giddens", Philosophy of the Social Sciences, Vol. 27 No. 3, pp. 283-308.

Schroeder, J. E. (2009), "The cultural codes of branding”, Marketing Theory, Vol. 9 No. 1, pp. 123-126.

Sewell, W.H. (1992), "A theory of structure: duality, agency and transformation", The American Journal of Sociology, Vol. 9 No. 1, pp. 1-29.

Siggelkow, N. (2007), "Persuasion with case studies", The Academy of Management Journal, Vol. 50 No. 1, pp. 20-24.

Spaargaren, G (2003), "Sustainable consumption: a theoretical and environmental policy perspective”, Society \& Natural Resources, Vol. 16 No. 8, pp. 687-701.

Stinchcombe, A.L. (1986), "Milieu and structure updated", Theory and Society, Vol. 15 No. 6, pp. 901-914.

Therkelsen, A., Halkier, H. and Jensen, O.B. (2010), "Branding Aalborg: building community or selling place?" in Ashworth, G.J. and Kavaratzis, M. (Eds.), Towards Effective Place Brand Management: Branding European Cities and Regions. Edward Elgar, Cheltenham and Northampton, pp. 136-156.

Thompson, C.J. and Arsel, Z. (2004), "The Starbucks brandscape and consumers' (anticorporate) experiences of glocalization", Journal of Consumer Research, Vol. 31 No. 3, pp. 631-642.

Van Ham, P. (2008), "Place branding: the state of the art", The Annals of the American Academy of Political and Social Science, Vol. 616 No. 1, pp. 126-149.

Vanolo, A. (2008), "The image of the creative city: Some reflections on urban branding in Turin”, Cities, Vol. 25 No. 6, pp. 370-382.

Vargo, S. L. and Lusch, R. F. (2016), "Institutions and axioms: an extension and update of service-dominant logic", Journal of the Academy of Marketing Science, Vol. 44 No. 1, pp. 5-23.

Warde, A. (2005), "Consumption and theories of practice", Journal of Consumer Culture, Vol. 5 No. 2, pp. 131-153.

Warnaby, G. (2009), "Towards a service-dominant place marketing logic", Marketing Theory, Vol. 9 No. 4, pp. 403-423. 


\section{Appendix A - Exemplary comments on the North Dakota promotional ad extracted from online platforms}

\section{Comments extracted from the Daily Mail Platform ${ }^{1}$}

Christopher, Canada, 7 years ago

The ad promotes obesity so I'm surprised it was deemed inappropriate.

Stuart, Canada, 7 years ago

I think the ads are sweet. Hey big girls need love too

$C F$, Canada, 7 years ago

You can go there and have all the nightstands you want, but if you get pregnant, don't try to get an abortion there...

Vovov, England, 7 years ago

I think the problem here is one of contextuality. Beside the other adverts, a common theme is clearly being continued. However, by itself the unfortunate implications of the word "legend", which maybe don't translate that well to Americans/older people, clearly make the advert distasteful. Due to the slangy use of the word "legend" and what it means to "be a legend" in colloquial terms, the implication of the advert seems crude. While I'm sure that those in charge of creating it did not pick this up, a good proportion of people would see it in this offensive way, and it was right to be pulled.

William Rae, Scotland, 7 years ago

Dinner, drink ... more drink, more drink, more drink ... wow, they're now thin, ha ha!

$J B$, Scotland, 7 years ago

People will complain about anything ...

Luca, England, 7 years ago

Oh it's such a shame they pulled it. That's a great ad. Arrive a guest, leave a legend. It sounds and feels good. I

think that their decision to pull the ad was wimpy.

Jeremy, England, 7 years ago

Well at least the ad attracted some publicity. Must be tough to get visitors to come to North Dakota. I should imagine that Mount Rushmore (in neighbouring South Dakota) is the main attraction to the region.

Welshgit, Wales, 7 years ago

Anyone else thought this was a condom advert?

Mors Magne, England, 7 years ago

North Dakota - that well known cesspit of depravity! ;o)

Toto Kubwa, Cyprus, 7 years ago

God I must be so naive I just saw young people having fun. I keep forgetting to be offended.

Alvaro Flores, USA, 7 years ago

Who would wanna go to North Dakota??? I didn't think people vacation there other than you know ppl from there.

Egbert Schwump, USA, 7 years ago

Why did they use fat girls in the ad?

\footnotetext{
${ }^{1}$ Comments are retrieved from http://www.dailymail.co.uk/news/article-2087621/Sexist-North-Dakota-tourism-boardadvert-pulled-sleazy.html.
} 
John Wanye, USA, 7 years ago

The only people complaining is house wives.

Lawrence, Fargo, 7 years ago

I really don't see what the noise is about honestly. I know the girls are hurt by the reaction. It looked very innocent. This is even more conservative as compared to what you see at night. Nonetheless, I find nightlife to be the best here. More than I have experienced even in big cities. These people know how to have fun.

\section{Comments extracted from the ABC Platform $^{23}$}

Michael, 7 years ago

Well, now we know why no one visits North Dakota. It's full of a bunch of backwards country nutcases.

Jim, 7 years ago

In the "nightlife" ad, what are promoting? That if I travel to North Dakota, hang out at a bar, there is a good chance I can hook up?

Karen Lee, 7 years ago

Seriously?????

Peter, 7 years ago

For years I thought North Dakota had very little to offer, so I did not visit. When I saw this ad, I thought it looked mildly sophisticated and an interesting place to visit. Now that I've seen the reaction in North Dakota, I've decided I was right in the first place and I don't need to go. Seems a little backward there, don't you think?

JrzWrld, 7 years ago

I think the people who objected to the ad are saying more about their own character flaws than anything else.

But I'm still not visiting North Dakota.

Jim, 7 years ago

Seriously?! Are you kidding me right now; people are upset about this? I wonder if the same people are upset by world hunger, our numerous wars abroad, diseases threatening millions of lives throughout the world on a daily basis...etc.

Greg, 7 years ago

Wow! I was expecting something overtly sexual by the headline. But for people to be upset by this? Those nutjobs make the Christian Right look like liberal extremists!! Hahaha. Maybe their slogan should be "North Dakota...where we never flirt with anyone!" Talk about uptight!

What, 7 years ago I would rather go to North Dakota for vacation, go out whatever, and have people that act real and will talk to you, rather than some other places to be "hip" and fake and get ripped off and what not!! What's wrong with REAL PEOPLE???

Ben, 7 years ago

Do these same people have a problem with the Vegas ads? I can't believe people are actually upset with this ad. There is nothing vulgar or inappropriate about it. The only thing that upsets me is the fact that the Tourism Board bowed to the infinite minority complaining about this and pulled the ad. STOP GIVING IN TO THESE PEOPLE!!!

Val, 7 years ago

Can someone from North Dakota PLEASE explain to me what is so racy about those ads?

DBLNN, 7 years ago

I'm from North Dakota and I don't see an issue with the ad, the people are not nutcases or backwards just very conservative, old school, the old folk still run the state, the community. There is change happening throughout the communities but it's a slow change. The only issue I see about the ad is the alcohol, casual drinking is all that most of the small communities have because the state is desolate, nobody wants to see the truth in their face let alone advertised. idk, it's a nice ad and very welcoming with friendly people.

Bri97, 7 years ago

People need to grow up and realize that in the real world that is what sells more. This type of ad shouldn't been pulled. So the ads that same the same thing showing people golfing, does that mean I'll become a pro golfer. Now doesn't that sound silly. Everyone needs to quit complaining about the stupid stuff and concentrate on what's more important in their lives. Gosh people get a life will ya.

BR9KD, 6 years ago

\footnotetext{
${ }^{2}$ Comments are retrieved from https://abcnews.go.com/Business/north-dakota-tourism-too-racy-forsome/blogEntry?id=15379501.

${ }^{3}$ The location of the commentator is not visible in the ABC platform.
} 
1

2

3

4

5

6

7

8

9

10

11

12

13

14

15

16

17

18

19

20

21

22

23

24

25

26

27

28

29

30

31

32

33

34

35

36

37

38

39

40

41

42

43

44

45

46

47

48

49

50

51

52

53

54

55

56

57

58

59

60

I am from North Dakota and while I agree that it is not an exciting place to visit...or a place I would want to vacation at ... I am NOT backwards!! Don't judge people and places you've never been to. There are crazy, backwards, stupid people everywhere ... 
Figure 1: The dynamics of place brands

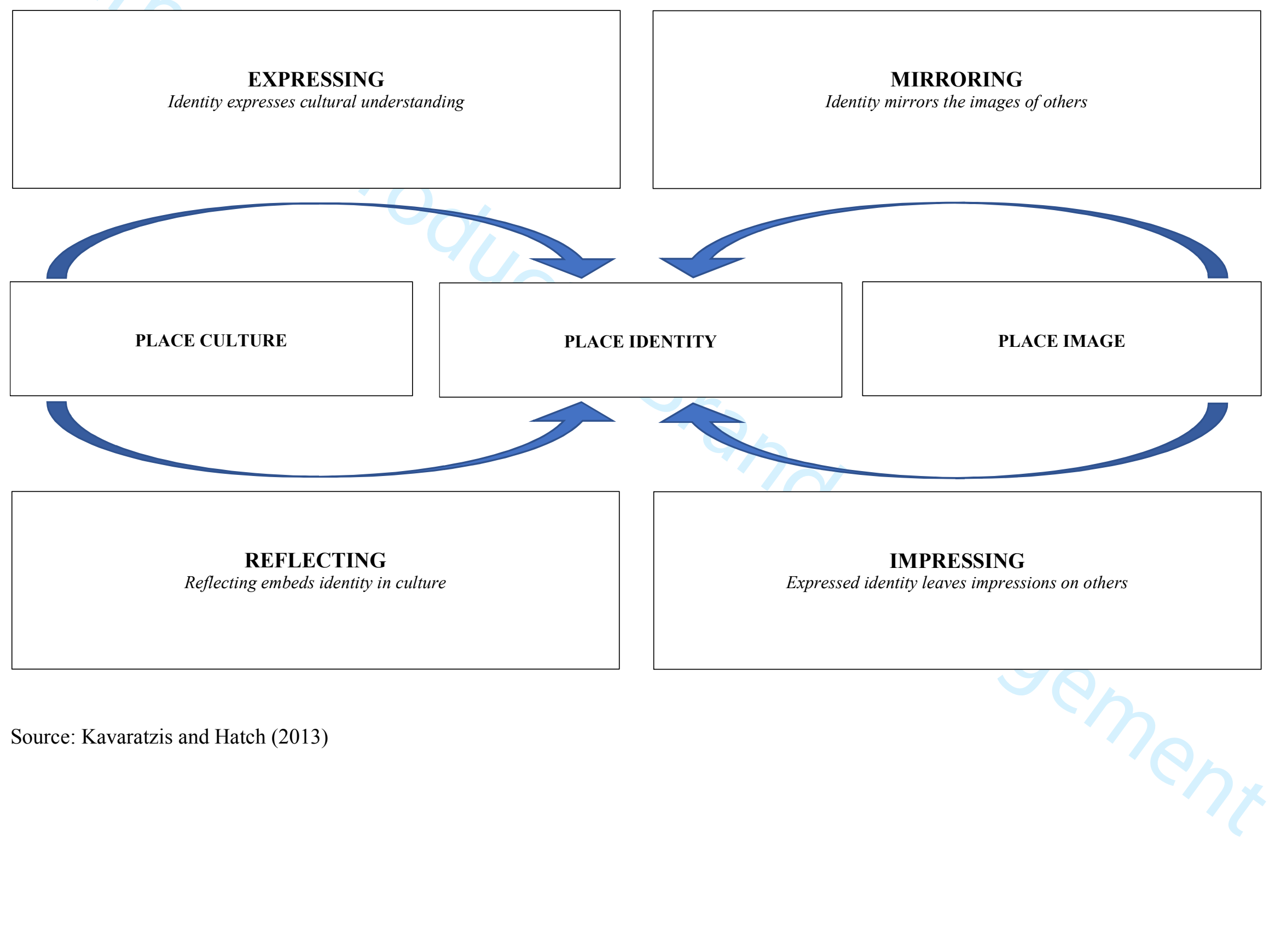


1

2

3

4

5

6

7

8

9

10

11

12

13

14

15

16

17

18

19

20

21

22

23

24

25

26

27

28

29

30

31

32

33

34

35

36

37

38

39

40

41

42

43

44

45

46

47

48

49

50

51

52

53

54

55

56

57

58

59

60

Figure 2: Representation of structuration theory

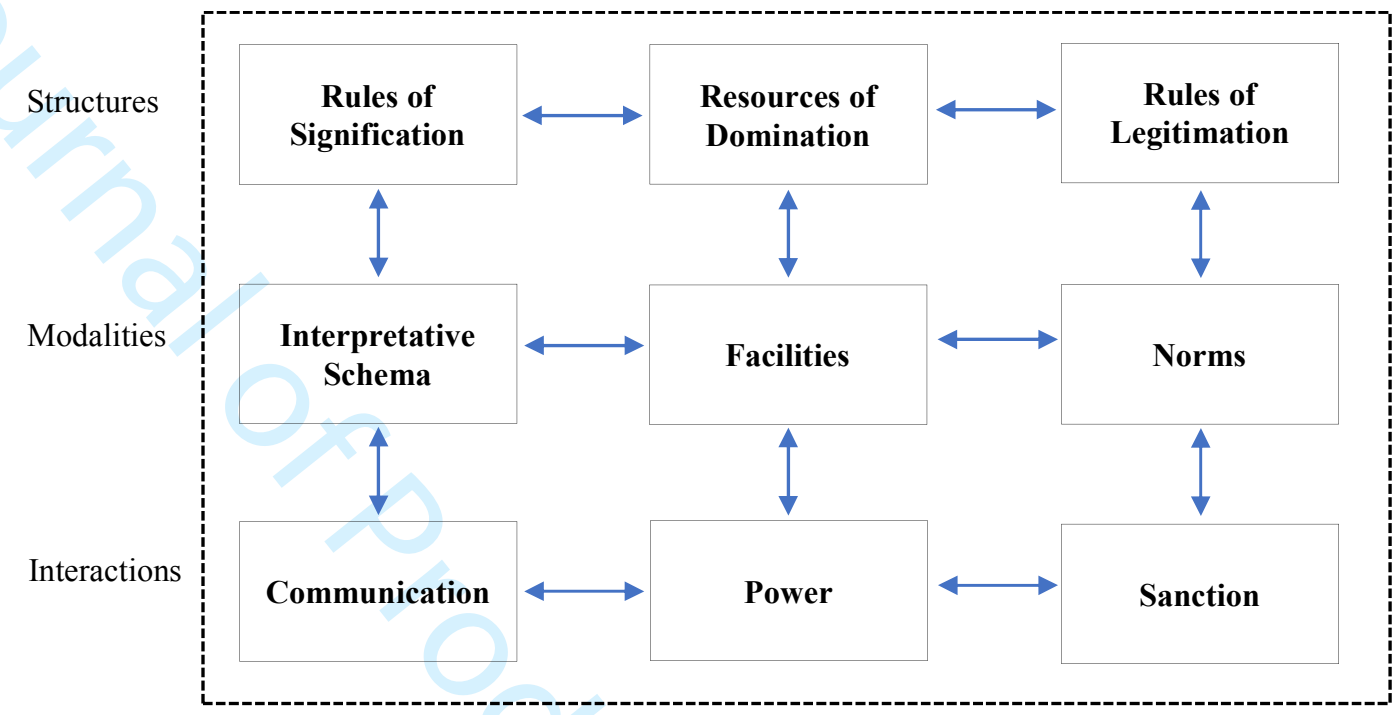

Source: Giddens (1984, p. 29) 
Figure 3: The structurationist dynamics of place brands

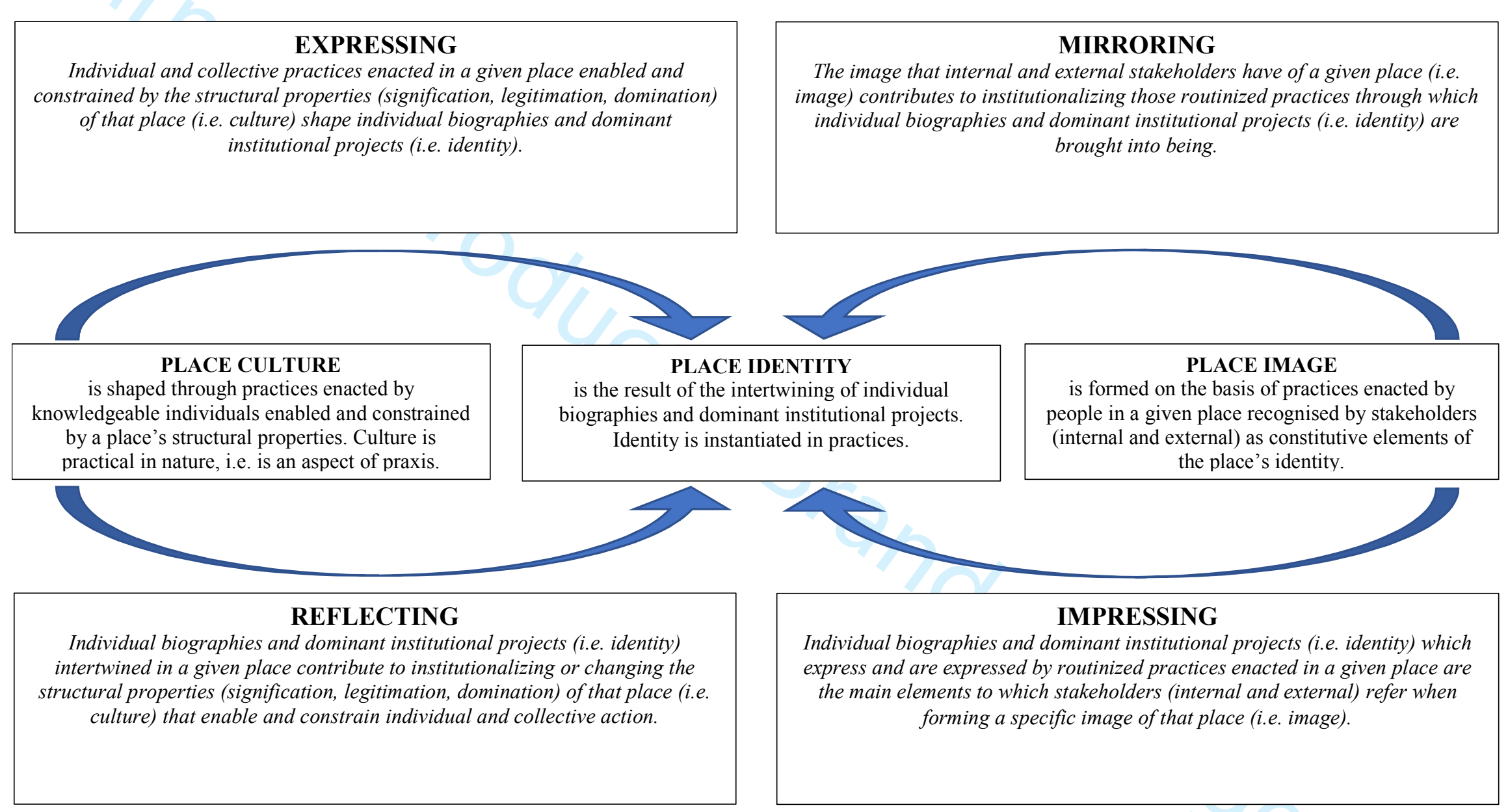


Source: Kavaratzis and Hatch (2013) 
Figure 4: The controversial poster of Fargo's nightlife

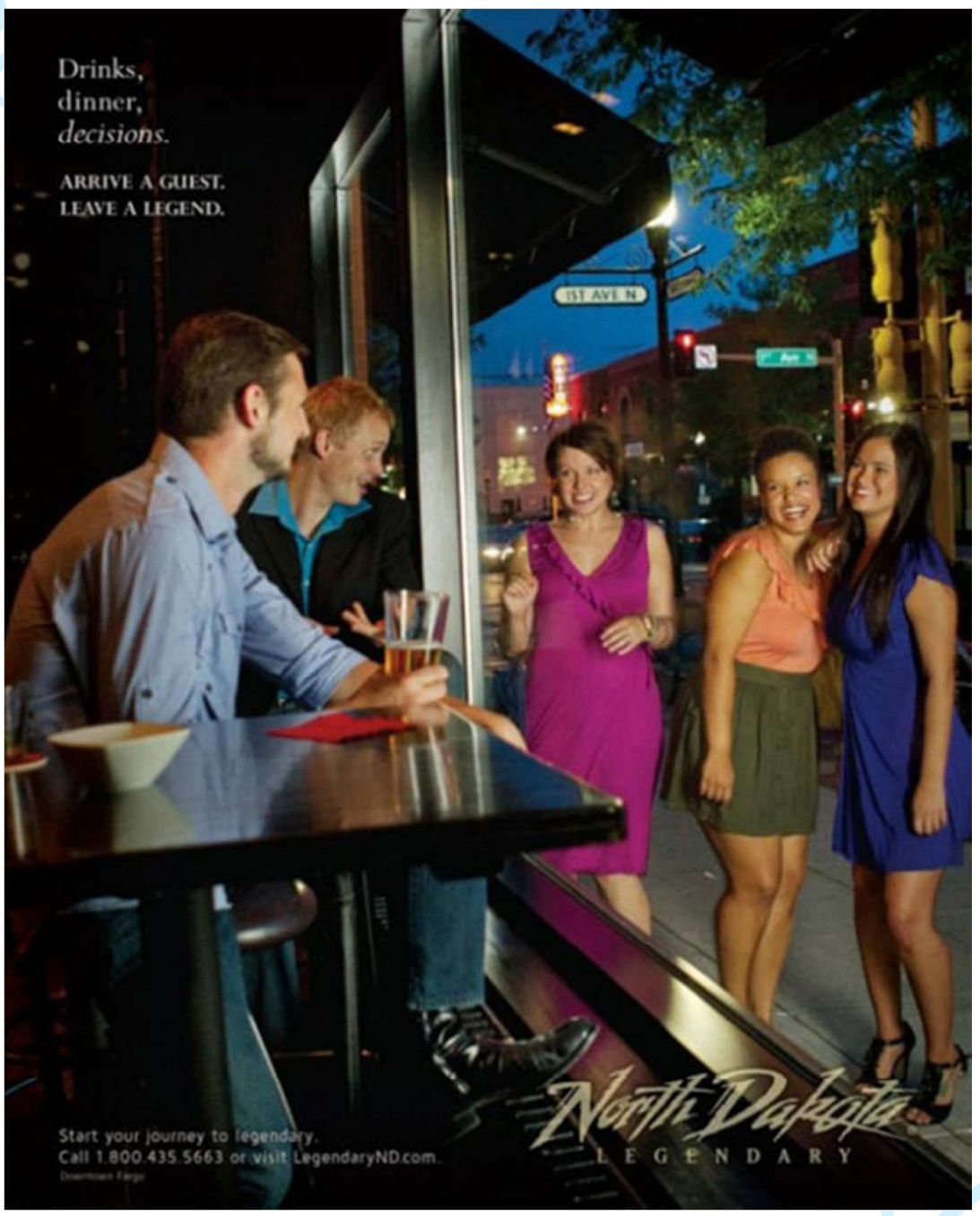

Source: retrieved online from www.adweek.com/creativity/north-dakota-baffled-outcry-overtourism-ad-137602/ 